\title{
Joseph Conrad's Lord Jim: Reconsiderations
}

\author{
Ali Albashir Mohammed Al-Haj \\ Faculty of Arts \& Humanities, Department of English\& literature \\ Jazan University, Jazan, Kingdom of Saudi Arabia .P o. Box 114. \\ E-mail:dr_abomathani@yahoo.com
}

Doi:10.7575/aiac.alls.v.5n.6p.212

Received: 25/08/2014

URL: http://dx.doi.org/10.7575/aiac.alls.v.5n.6p.212

Accepted: 21/10/2014

\begin{abstract}
The present study aims at reconsidering critically Joseph Conrad's Lord Jim. Joseph Conrad is a great master of English prose who writes normally of the sea, of the Eastern islands, of the English character as seen against a background of the exotic or faced with difficulties. The power of Conrad's feelings for Jim, as well as the force of his judgment against him, are the responses of a man mightily involved on two planes, one personal and one public, with the dynamics of good and evil. The evil in Lord Jim is one thing on the surface and another beneath our grasp. It is of course the evil of men who have no sense of loyalty to anything.
\end{abstract}

Keywords: Joseph Conrad, reconsidering, Lord Jim, the sea, good, evil, English character, loyalty

\section{Introduction}

Many of Joseph Conrad's novels are based on the classic adventure story but they rarely end at that. He is a master of complex narrative techniques, and such devices as time shifting and changing viewpoints. He tends to show characters in extreme situations, testing themselves and being tested, not always with success. As Cedric (1989) opines:

Joseph Conrad's characters do not always survive that test, one of the most famous examples being Kurtz in Heart

of Darkness, who is found to be 'hollow at the core' and thus crumbles under intense pressure.(p.45).

Conrad is both a romantic and a modern writer; his search for truth and certainty inside a man, his belief that in the final count it is our own reserves and resources that we lean on, and his fondness for mystery and vague uncertainty are all romantic. The elements of uncertainty, sense of corruption, and loss of direction and purpose are all very modern. According to Stape(1996):

Conrad is a Romantic author in his search for inner truth, certainty and insight within a man, in his belief that the final count what we all rely on is what we carry within us, and in his fondness for mystery.(p.2)

Conrad believes in faithfulness or fidelity as a prime human virtue, and darkness is a potent symbol in his novels. Roberts (1993) has rightly pointed ':

Conrad stated that fidelity is one of the prime human virtues, though it is open to debate whether or not this always carried through into his novels.(p.78)

At his worst, Conrad presents a vague and rather insubstantial romanticism; at his best, he presents a powerful, mystifying, and symbolic vision of modern man. As Cedric (1989) opines:

Conrad's weaknesses are a tendency to present a rather vague, wordy and insubstantial Romanticism, his inability to present effectively love relationships, women, and a slight tendency to oversimplify. His strengths are the taut control he can wield over a novel, his penetrating and mystic insight into the heart of modern man and the sheer power of the vision he can create.

Unlike many novelists who draw upon the geography, customs and idioms of their native region for the creation of their art, Conrad's characteristic subject was not Poland but the sea, and he wrote neither in his native tongue nor in French, his second language, but in English, which he first started to speak around the ages of twenty. His artistic career is singular and impressive. His first novel was published when he was nearly forty. When he died at sixty-seven he was the author of a long shelf of books; he had by then won both modest popularity and the esteem of such literary men as Henry James and Andre Gide. His reputation, which was faded for fifteen or twenty years after his death, is now very high and his work is the object of considerable critical inquiry. The current study aims at reconsidering critically one of his work, Lord Jim, his most widely read novel.

\section{Joseph Conrad's Contribution, Reputation and Writing Career}

\subsection{Joseph Conrad's Life: Family and Social Background}

Joseph Conrad (his real name was Josef Konrad Korzeniowski) was born in 1857 in Berdichev, Ukraine (then part of the Russian Empire), to a Polish patriot in exile in Russia for his nationalistic activities. Conrad was orphaned at eleven of age and he was brought up by a maternal uncle, who sent Conrad to school at Krakow, and then to Switzerland, 
Conrad, however, was bored by school and his one true ambition was to go to the sea. His chosen career was an odd one for a boy of good family was the sea, and in the years between 1874 and 1896, he served on or commanded French, Belgian and British ships, on voyages all over the world, which sowed the seeds of numerous novels and stories. As Barnard (2001) opines:

In 1874, Conrad began a twenty - year career as a sailor. He joined the British merchant navy and travelled to places such as the West Indies, Malaysia and the Congo, this latter, extremely difficult journey, marked by a severe illness, haunted Conrad and is the subject of his nightmarish tale Heart of Darkness(1902).(p.140) .

\subsection{Joseph Conrad's Contribution, Reputation and Writing Career}

In his early years as a writer, Conrad made his name as the teller of tales of the seas, and the remoter parts of Empire. They were never' good yarns' in the popular sense, but stories in which the codes men live by are tested, in which man is forced to look into himself and see the realities beneath the civilized veneer. For such testings and self-explorations, Conrad's life at sea had equipped him. He was conservative in his attitudes, without illusions about men and motives, yet still in touch with the youthful romanticism that had sent him to sea, still able to recapture the thrilling novelty of travel, adventure, the exotic, the unknown.

I see it now-the wide sweep of the bay, the glittering sands, the wealth of green infinite and varied, the sea blue like the sea of a dream, the crowd of attentive faces, the blaze of vivid color-the water reflecting it all, the curve of the shore, the jetty, the high-sterned outlandish craft floating still.... (Heart of Darkness, 1996 p.45)

His works were inspired by his journeys, hence the exotic and lush landscapes and romantic atmosphere. However, Conrad exploited the sea and life on ships as a background against which to set the ambiguities and moral dilemma s of the individual. He thus analyzed men and their reactions in exceptional circumstances, put under the test of loneliness and extreme situations. This is exemplified in Lord Jim (1900),Typhoon (1902) and Nostromo(1905), where the characters 'values and qualities, tested in a moment of crisis, reveal their inadequacy and cause conflicts or tragedy. The complex and at times paradoxical nature of relationships is explored in the novel The Secret Sharer (1912), where the main character is compelled to face his own moral opposite Ford (1991) has rightly pointed out that:

Conrad wrote at an exhausting pace- stories, novels, personal reminiscences, essays- and yet, as we know from his correspondence, writing caused him great anguish and he was rarely satisfied with what he wrote. His instinctive seriousness, his devotion to craft, along with a wavering faith in his own genius made Conrad's profession as a writer an almost daily struggle. His fame grew slowly but he was acknowledged as a writer of the first rank long before he became popular.(p.54)

The condemnation of the cruelty and greed of colonialists is another theme of Conrad's novels, especially Heart of Darkness, which dramatically describes the effects of the brutal exploitation of Africa by European colonial powers. The theme of the story is again choice in an alien environment: the white man in the unfamiliar and unfriendly environment of the Congo can either become a ruthless businessperson who sees Africa as an immense source of profit, or become, like Kurtz, the dark personification of degenerate idealism.

The great work of the first part of Conrad's writing career, the turning -point, was Heart of Darkness, and it concerned a turning -point in his own life, his brief command of a river steamer in the Belgian Congo in 1890.' Before the Congo I was a mere animal' he said later. (Krieger, 1989, p.67). In the years that followed, the British were to learn more of the reasons why it was so crucial an experience for Conrad, for it was in the early years of the century that the full, disgraceful story of King Leopold of the Belgians' colonization of the Congo was to emerge- a story of greed, trickery, brutality and enslavement. It was this, the shabbiest colonial enterprise in the whole history of nineteenth-century colonialism that Conrad saw at first-hand and made the stating points of his great short novel.

In his great novel, Nostromo, Conrad examines critically some Victorian assumptions about society, progress and enlightenment, and finds them empty. In this novel, he creates an imaginary state in South America, Costaguana. Though Conrad's actual experience of the area amounted to only a matter of days, it is a totally convincing, solid, haunting creation. We see the progress of Costaguana from a Spanish colony, represented by the statue of the Spanish king in the main square, through the corrupt, inefficient or simply barbaric dictatorships that succeeded' liberation', to the establishment of a stable modern state, or one with the appearance of stability.

Insofar, as Canard's stories reflect his melodramatic experiences at sea and his journey in strange, out-of-the- way places, he appears romantic. Essentially his greatest skill lies in his capacity to evoke an atmosphere, whether of a typhoon at sea of the sultry mystery of the jungle. And this he does by a treatment as careful and detailed as that of the realists.

To conclude, in all his works, Conrad made extensive use of symbolism and striking visual imagery. He tried to convey the complexity of experience by experimenting with narrative technique. Several of his stories are told from multiple points of view. His creation of an intermediate narrator- Marlow in Youth(1902), Heart of Darkness, Lord Jim and Chance(1914)-who, although involved in the action, sticks to the facts in his storytelling, anticipates the narrative technique of modernist novels where the narrator totally disappears. 


\subsection{Joseph Conrad and Idea of Lord Jim}

Lord Jim took shape by stages in Conrad's mind, and the focus of the book was enlarged greatly as Conrad worked at it. When he began the book in May 1898, he called it" Jim, a Sketch," and conceived of it as a short tale describing only the pilgrim episode.( Gorodn,1988,p.34). The story was put aside several times for the writing of others ("Karain," " Youth," and " Heart of Darkness"), and for repeated attempts at The Rescue, which took many more years to complete. Conrad did not work steadily on Jim again until September 1899. The novel was finally completed in June 1900. It was published in monthly installment in Blackwood's Magazine from October 1899 to November 1900, and in book form on October 15, 1900. In spite of warm praise by William Galsworthy, and Henry James, among others, and moderately enthusiastic reviews in England and America, the novel was initially unpopular. Conrad himself was deeply apprehensive about the novel, sensitive of its flaws, uncertain of its chance for survival.

\subsection{Lord Jim as Conrad's most Appreciated Novel}

Lord Jim is today Conrad's most appreciated novel and many consider it his most characteristic work of art. Whatever the defect of this" free and wandering tale" (Gorodn, 1988, p.92) in it Conrad brought to dramatic fulfillment his own most persistent: and finally unanswerable questions about the nature of man. In its probing, oblique, resonant fashion the story of Jim, " a simple and sensitive character," does, as Conrad hoped it would," color the whole sentiment of existence." (Ford, 1991, p.37). Jim is, as Marlow insists again," one of us." (Lord Jim, p.68). In Marlow's unrelenting attempt to see Jim whole, to account for both his fine aspirations and his cowardice, to judge him fairly, readers recognize their own difficulty in assessing characters in the twentieth century. For Conrad as for readers, there is no last word on man, and while they may yearn nostalgically for the unambiguous heroes of earlier cultures, it is in figures like Jim and Leopold Bloom and Thomas Sutpen, to take three extreme examples, that readers discover their own authentic heroes and the " sentiment of existence" which is uniquely theirs.

Lord Jim, of course, must be judged in terms of its own form, but such Conrad's achievement. One of the ironies of authorship is Conrad's own low opinion of this fine work just after he had finished it. On November 12, 1900, he wrote sadly to Edward Garnett:

For what is fundamentally wrong with the book- the cause and effect- is want of power. I do not mean the 'power' of reviewers' jargon. I mean they want of illuminating imagination.( Mudrick,1988,p.58).

\subsection{The Main Theme of the Novel: At A Glance}

Conrad raises the significance of Jim's action to a metaphysical level and in his portrayal of Jim's Odyssey, explores the theme of guilt and atonement .Every character and every incident is subordinated to and intended to develop this theme( Howwitt, 1997,p.13). However, it is so intricately worked out that it is sometimes difficult to grasp the purport of a remark or an episode. And, as in Heart of Darkness, one may be tempted to wonder whether even Conrad himself was always quite clear as to what he was trying to say or, in this case, whether there was not some unresolved ambiguity in his own attitude to the events described.

Conrad used the device of Marlow to record a situation in terms of his sensations. His role was now, as a character in the book and as Conrad's mouthpiece, to probe, analyze, and comment on the states of mind of another. There was to Conrad the cardinal sin of breaking the illusion with the obtrusion of his own comments. Marlow then was the chief device for developing the theme. But, in addition, Conrad used a number of characters and incidents as moral touchstones for Jim's situations.(Karl,1992.p.45).

\subsection{The Story of the Novel}

Conrad's finest book is perhaps Lord Jim, where moral conflict is admirably presented in the character of the young Englishman who loses his honors through leaping overboard when his ship seems to be in danger ,but expiates his sin by dying heroically at the end.

\subsection{The Strength of Lord Jim}

The strength of Lord Jim derives largely from Conrad's facing of an issue which takes form in the earlier tales but which gains ultimate expression only perhaps in the nocturnal panorama of Heart of Darkness. The crisis underlies Marlow's brooding over a question, which seems to him to affect humankind's conception of itself. His interest in Jim extends to the larger problem of the application of a fixed standard of conduct to the individual in every circumstance; for the fact that the standard does not hold for Jim in his supreme test on the Patna casts double upon its validity.(Zabel,1988,p.69).

The scene between Marlow and the French lieutenant has always been praised; and a main reason why it grips the reader is that here Marlow presses to the utmost, and without positive results, his query as to whether such a standard can be effective at all when a man, in a case like Jim's, is beyond the check of common opinion . To operate successfully, the rule should enable the conflicting elements in the individual to work harmoniously to the end of purposive action; and its failure to do so for Jim on the Patna indicate that, when the division is absolute, man falls away from the control of the community. The one remaining safeguard is, then, perhaps a simple eye for danger like that of Singleton or of the native youth, Dain Waris, in Lord Jim who sees at once the evil of Brown, which deceives and betrays the visionary Jim. After Lord Jim, at any rate, characters who have this primitive eye for fact without the benefit of adequate mental recourses appear more frequently in Conrad's early work. (Karl, 1992.p.85).

\subsection{The Depiction of Jim as the Prototype of a Good Boy}


Jim is the prototype of the boy who" makes good", but what Conrad does is to explode the popular stereotype by ultimately defining the "good" in qualitative and spiritual instead of quantitative terms. We find, on inspection, that the success story is not entirely alien to the Oedipus myth. For Oedipus, too, has" Ability in the abstract'; he has talent for saving a distressed community, as Jim has. Jim's "success" comes after he has sought to escape the truth by moving from port to port, just as Oedipus has sought to evade destiny by a change of scene-both versions of the common myth of- " leaving town". When at last there is nowhere else to retreat to, they discover their deepest talents; for both the ultimate deed is a paradox, success -in- failure. (Howwitt, 1997, p.89)

\section{Conclusion}

Lord Jim is not a study of a romantic young man redeeming a terrible moment of cowardice by later bravery and selfsacrifice, nor is it a study of a weak young man whose vanity makes him unable to come to terms with his weakness. Yet each of these descriptions is some sense and in some degree true. Jim's final act of surrendering his life is heroic, though it is also exhibitionist and useless. In addition, in a sense his failure on the " Patna" was not a straightforward act of betrayal or cowardice. The cause was partly his too lively imagination and imagination, we must remember, is the sympathetic faculty which destroyed the morale of the crew of the " Narcissus." Jim visualized with great clarity what would happen if the packed body of sleeping pilgrims were to be awakened to a sense of their inevitable doom; he saw in his own lively mind the panic and horrors; and as a result he allowed himself to believe that it would be best for all concerned if they sank quietly and asleep with the ship. But the ship didn't sink, and Jim's decision become in cold, objective fact, a gross dereliction of duty. Jim will never admit that it was a decision; it was something that happened to him.

\section{References}

Barnard, R. (2001). A Short History of English Literature. London: Longman.

Cedric, W. (1989). ALiterary Life of Joseph Conrad. London: Macmillan.

Conrad, J. ( 1988). Lord Jim. London: Pan Books.

Ford, M. (1991). Joseph Conrad. A Personal Remembrance. London: Roberts Hale.

Gordon, J.D. (1988). Joseph Conrad: The Making of a Novelist. Cambridge: Cambridge University Press.

Hewitt, D. (1997). Joseph Conrad: A Reassessment. Cambridge: Cambridge University Press.

Karl, F. (1992). A Reader's Guide to Joseph Conrad. London : Longman..

Krieger, Murray. (1989).The Tragic Vision: Variations on a Theme in Literary Interpretation. London: Macmillan.

Mudrick, M. (1988). Joseph Conrad: A Collection of Critical Essays. London: Macmillan.

Murtin, R.C. (ed) Joseph Conrad 's Heart of Darkness. London: Macmillan

Sherry, N. (2001). Conrad's Eastern World. London: Longman.

Stape, J. S. ( 1996). The Cambridge Companion to Joseph Conrad. Cambridge: Cambridge University Press.

Zabel, M.D.(1988). Craft and Character in Modern Fiction. London: Macmillan. 